\author{
ALEKSANDRA KULPA-PUCZYŃSKA* \\ Warsaw, Poland \\ ORCID ID oooo-0002-5440-3310
}

\title{
UNIVERSITY SPACES FOR COOPERATION STRENGTHENING PRO-INNOVATIVE ATTITUDES OF ACADEMIC COMMUNITY
}

\begin{abstract}
The article and its undertaken matter are part of the discussion on the pro-innovative nature of a university - featuring examples of (mainly educational) activities which boost innovation on the university campus and beyond, and referring to trends occurring in the analysed areas. The presented content has been limited to the social dimension of innovation, which among other things, changes the way of perceiving the world and interpersonal relations, also in terms of organization of workspaces and (co) working methods. The purpose of the article is also to draw attention to the participation of students, academic teachers in various activities (also pro-innovative ones) taking place within a non-traditional social infrastructure. Problem analysis was based on literature studies, including reports on research on innovation as well as on the author's professional experience related to new ${ }^{1}$ spaces of education - and an attempt to answer the question: "Can cooperation within the described spaces strengthen pro-innovative attitudes, including the attitudes of future pedagogues?"
\end{abstract}

Keywords: university, spaces for cooperation, pro-innovation attitudes, academic community, education for innovation, cooperation between universities and the local environment.

* Aleksandra Kulpa-Puczyńska, Doctor of Humanities with specialisation in pedagogy; Assistant Professor at the Faculty of Education at the Cardinal Stefan Wyszynski University in Warsaw. She focuses on issues concerning preparation to professional work, collaboration of schools with business entities and entrepreneurial activity of young people in the dynamic professional reality. Her academic contribution consists of over 50 publications, including articles, mainly in the field of labour pedagogy and andragogy. She is a member of the youth Pedagogy Panel operating at the Committee of Pedagogical Science of the Polish Academy of Science (PAN). She can be contacted at: a.kulpa-puczynska@uksw.edu.pl.

1 This concerns, as it does in the case of innovation (broader definitional approach), an element of novelty. For example, a product, process, or organizational method have already been implemented in other companies, however they are new to the given company. Innovations are also the result of cooperation among companies or their collaboration with public research institutions, they can also be created outside the enterprise (European Commission \& OECD, 2005); Innovation is understood as "an idea, practice, or object that is perceived as new by the receiving person or entity” (Rogers, 2003, p. 12, after: Matusiak, 2010, p. 21). 


\section{Innovation and cooperation - an introduction to the problem set out in the title}

The entrepreneurial and pro-innovative nature of the academic environment (with regard to its internal potential), which also directs its attention to the dissemination of scientific achievements and pursuing a commercialization policy (combining the needs of science and the market), was described by the author, among others in the publication: „Higher school as an institution supporting innovative activities held by companies. Selected problems" ${ }^{2}$. In this article, taking into account the main problem, certain issues related to the structure of innovative organizations which create opportunities - spaces for: interaction and cooperation, creativity supported by motivational systems, learning and development by involving employees in rationalization activities have been elaborated on (Tidd, Bessant, 2011). It is, among others, in the properties of the network of relations (their nature, diversity, durability, range) - according to Piotr Sztompka (2016) - where one should search for human entrepreneurial and innovative potential. The atmosphere of the interpersonal sphere - created by openness, partnership and trust - is also of great importance. On the other hand, pro-innovative attitudes of employees are crucial for the efficient functioning of an organization, including a university. It is about individual behaviour characteristics or actions, such as "[...] openness to new solutions, manifested, among others in learning skills, readiness to take risk, criticism of existing patterns and standards of conduct" (Drozdowski, Zakrzewska et al., 2010, p. 20). The purpose of the study is also to emphasize, based on research and expert positions - the statement of among others Joanna Madalińska-Michalak (2020), saying that innovative behaviour is searching for and implementation ${ }^{3}$ of new working methods, techniques and tools. For example, as a part of the creation of (inter-departmental - author's note) task-based teams or the implementation of educational and social programs carried out with the participation of external partners (Drozdowski, Zakrzewska et al., 2010). The article was also inspired by reports emphasizing that analytical thinking and innovation, complimented by critical thinking and problem-solving skills, are prospective skills that are and will be in demand in the future (Vincent-Lancrin et al., 2017; World Economic Forum, 2020).

2 Detailed information about the article can be found in the bibliography.

3 The innovative process consists of three phases: creative - development of a new idea (related to the academic community); entrepreneurial - including adapting the product to customer needs and commercial - market verification constituting the innovation (Matusiak, 2010, pp. 43-44). Innovation should be improved and corrected, so that it can bring the assumed full success (Grudzewski, Hejduk, 2004, p. 246). Moreover, innovations concern various areas of education, they are the result of an action, creativity, and pedagogical progress (Przyborowska, 2013, pp. 49-50). 
Paul Temple, in his paper "University spaces: Creating cité and place" (2019), writes that "[...] In a university, spatial practice might include studying, researching, teaching or socializing, with these activities mostly taking place in predetermined locations" (p. 225). There are also examples of university buildings that meet the needs of students and staff in an inventive way, strengthening their social capital (Trow, 2010, after Temple, 2019). They include, among others the principles of universal and participatory design, and a "new" approach to learning - in various circumstances (learning opportunities associated with place/space; learning by making; shared learning) - see for example the Innovating Pedagogy Reports. Hence, taking into account the background outlined in the introduction, in the context of issues related to the subject-matter ${ }^{4}$, an attempt was made to present the selected - complementary to the traditional lecture rooms - academic areas of education, cooperation and innovation. In this view, reference (also following other authors) was made to case studies. We are talking about creative, common spaces such as business incubators and classes conducted with the participation of career offices or in cooperation with coworking spaces, as well as simply about a space for creativity (expressing ideas) and exchange of experiences, including the openness of the environment to new projects using e.g. innovative technologies and/or participation of unobvious partners. The aforementioned latter approach to the problem is also consistent with thematic workrooms carrying out innovative work programs and didactic aids, also co-created by groups of teachers (often in cooperation with other specialists, companies), innovative laboratories, studios, but also university/faculty corridors transforming into artistic spaces displaying products created by the students and the teaching staff. At this point, it is worth mentioning, for example, the exhibitions of works organized at the Faculty of Education of the Cardinal Stefan Wyszyński University by the Scientific Circle of Special Pedagogues. The initiatives and works of young artists (students) are presented on the faculty's website.

\section{Non-standard spaces for educational, pro-innovative activities. Cooperation of universities with the local environment}

The strengthening of pro-innovative attitudes among young adults, including future pedagogues, is possible through enhancement of practical education, including the organization of internships in innovative companies and institutions.

4 I also took into account the results of the theoretical analysis related to the implementation of an original project financed from research funds: "New" spaces for education and creative cooperation - opinions and experiences of pedagogues as well as students and graduates other fields of study (DEC-IPG-9/21). 
Universities are increasingly starting to cooperate e.g. with coworking spaces ${ }^{5}$, providing students with another access to advisors, experts, mentors and successful entrepreneurs - their skills and experiences. Thanks to the above-mentioned cooperation, they provide students with the opportunity to participate in courses preparing to become an entrepreneur or an opportunity to establish cooperation with specialists from a given industry and/or with peers - coworkers characterized by various competences, and therefore ensuring favourable conditions for planning and implementing their own, often innovative, projects (Cagnol, 2013; Eurofound, 2015), also artistic and social ones, which - according to the author of the article - should interest pedagogues and educators. In online publications containing current information on coworking, you can read, for example, that in an environment designed specifically for work, students get an opportunity to: a. discover new career paths and forms that support combining studying with working; b. expand the network of contacts with the labour market in mind; c. develop the skills needed for working in a team and during discussions - to present their arguments and listen to the opinions of others, and to strengthen design thinking used in solving, among others social problems - here, an example can be activities (initiative of coworking space and university) conducted at CoCo in Minneapolis (Duarte \& Mendes, 2016; Jonhson, 2021). In addition, today's coworking spaces are becoming spaces for development, which encourage active and collaborative learning/studying ${ }^{6}$ and constitute a part of the new urban social infrastructure (Stachura \& Kuligowska, 2018), e.g. conferences, lectures with interesting speakers, workshops ${ }^{7}$. These events may be co-organized by a university.

It should be added that coworking is also offered by academic business incubators (AIP). Co-working zones adapted for studying, working and resting are also created

5 Work in coworking spaces (the concept of work - characteristics, advantages and disadvantages, determinants of development) has been subject to a broader analysis in the study: A. KulpaPuczyńska (2019). Individual Entrepreneurship in the Context of Diversity and Flexibility of Workplaces. In Tipurić, Darko Hruška, Domagoj (Eds.). 7 th International OFEL Conference on Governance, Management and Entrepreneurship: Embracing Diversity in Organisations. April 5-6. Dubrovnik, Croatia. Governance Research and Development Centre (CIRU). Zagreb, pp. 340-350. Retrieved from: https://www.econstor.eu/bitstream/10419/196091/1/ofel-2019-p340-350.pdf.

6 An example of this can be Regus Centers and their initiative - open to students coworking spaces in Brussels, https://magazines.regus.com/en-pl/students-welcome-at-coworking -spaces-in-brussels/.

7 Educational and networking events (also online) are held, for example, at Campus Warsaw a space for startups initiated by Google (https://www.campus.co/warsaw/). Google Campus and Centrum Koneser have been assessed by the citizens of Warsaw (who have described the Campus as a multifunctional undertaking, fulfilling the promotional function and attracting young talents) as investments supporting the development of the Praga district. After: Google for Startups (2020). Tak tworzyla się historia - 5 lat Google for Startups w Europie ŚrodkowoWschodniej [Five years of Google for Startups in Central and Eastern Europe], pp. 46-61. The report is available on the Campus Warsaw website. 
in university libraries and student dormitories. However, in the dynamic situation of the COVID19 pandemic, the possibilities of the mentioned areas were limited. On the other hand, in the conditions offered by remote education, people studying in large cities could/can take advantage of comfortable, adequately equipped, creative spaces for learning outside their homes (and benefit from the support of other coworkers/students) and learn about the possibilities, advantages, disadvantages of remote work.

Not only university libraries can be places where the inventive and motivating peer collaboration and student - lecturer cooperation, with the support of library staff, take place. Public libraries are increasingly adapting their equipment and infrastructure to joint educational and social activities, also inviting groups of students, e.g. who work on interdisciplinary projects (Sinclair, 2007). The today's offer and initiatives of libraries also contain creative practices in areas related to digital technology, including access to modern hardware and software and the creation of physical spaces and time spaces for meetings of people who have similar interests, also (pro)professional. The above mentioned activities are characteristic of the informal, social learning environment - The Edge State Library of Queensland in Brisbane (Bilandzic \& Foth, 2013), a project proposing, among other things, participation in various events (community lab sessions, workshops, exhibitions) and specific, open zones e.g. Digital Media Lab or Recording studio ${ }^{8}$. As it can be seen, in today's library spaces, which are searching for new proposals, especially for young people, various types of makerspaces can be noted. They offer stationary or mobile access to modern tools and services as well as activities that help implement individual, often innovative ideas. They are an example of libraries developing educational activities (e.g. experimenting with digital technologies, working with the design method with non-standard topics). Libraries organize their creative makerspaces ${ }^{9}$ also in cooperation with partners, e.g. higher schools and teaching staff (Koszowska, 2019). Universities ${ }^{10}$ undertake to form their own, innovative spaces using the universal design principles - taking into account the needs of various groups of users: students with disabilities; representing different backgrounds and cultures; characterized by a wide range of skills, etc. (The College of Engineering and DO-IT website, 2021).

There are also digital fabrication laboratories arising in universities and technology parks - being physical spaces (and online communities) providing

8 You can read about the activities and initiatives of the library, among others at: https://www. slq.qld.gov.au/plan-my-visit/spaces-visit/edge.

9 More information: Creativity clubs in libraries - a program implemented by the Information Society Development Foundation (FRSI): http://www.klubykreatywnosci.org.

10 See for example the AccessEngineering project, The College of Engineering and DO-IT (Disabilities, Opportunities, Internetworking and Technology) at the University of Washington: https://www. washington.edu/doit/making-makerspace-guidelines-accessibility-and-universal-design. 
advanced materials, technologies and offering the assistance of specialists/mentors. They support the development of competences: IT skills, entrepreneurship, cooperation; integrate practitioners and local learning environments; are technical assistance for cultural institutions that may become part of the above activities. Fab labs build a creative community which includes, among other researchers, young entrepreneurs, practising pedagogues (Orzeszko, 2020).

According to Article 148 of the Act of July 20, 2018: Law on Higher Education and Science: "1. Universities can run academic business incubators and technology transfer centres. 2. An academic business incubator is established to support the economic activity of university employees, doctoral students and students" (Journal of Laws 2021.478, consolidated text). In addition to the offer of innovative services supporting the development of young people's interests and, as a result, the implementation of their business ideas, academic business incubators provide practical knowledge and offer advice, also supporting the didactic process (Siemieniuk, 2017). Technology transfer centres (CTTs) belong to the basic centres of innovation ${ }^{11}$ and entrepreneurship, and are also known as support institutions, bridging units. They constitute a multifunctional (informational, training) link of the university's contacts with the environment. Another operational direction of the centres' is the cooperation with small and medium-sized enterprises, which includes offering assistance in acquiring new technologies and specialist knowledge. There are university CTTs having a large budget, a team of employees and experts, and small centres which become active when external financing is obtained (Matusiak 2010; Bąkowski 2012). The above-mentioned units and their tasks can be included in the model of an "entrepreneurial university", which - taking care of the intellectual and cultural values, while constituting an important part of society - is also properly adapted to the market. The idea of an "entrepreneurial university" is the pursuit of the best possible combination of conducting research (especially in the field of future-oriented fields), creating innovation and intellectual development of students, including those who are well prepared for work (Marody 2014; Przepiórkowski, 2018).

\section{Trends in the described academic areas of cooperation - conclusions}

Working and studying, e.g. in coworking centres, brings an opportunity for joint activities in environmentally friendly, flexible spaces (due to the place and time of work), where taking care of the psychophysical health of employees is becoming more and more important and the effects of work are noticed first. According to the World Economic Forum (2020) report cited in the introduction, the importance of

11 At the Cardinal Stefan Wyszyński University in Warsaw, there is a university-wide Center for Digital Science and Technology (CNT), which undertakes research, development and educational activities: https://cnt.edu.pl/. 
well-being in managing remote and hybrid work is growing, while self-management skills and competences - highlighted in the previous considerations - are equally important. So, can the cooperation (e.g. of students) within the above-mentioned, analysed spaces/practices also strengthen pro-innovative attitudes?

Thanks to the cooperation between universities and coworking offices, students are provided with another opportunity to become familiar with creative work environments and experience the changes taking place, among others in the organization of professional work (similarly as teachers). They can strengthen their practical preparation, skills or commence the implementation of plans related to starting their own business. In turn, academics can develop their didactic workshop, gain practice by cooperating with various groups of students and establish new professional contacts. It happens that students become teachers for other coworkers - it can be an interesting experience for young educators.

Libraries of the future will expand socio-spatial and technological possibilities (e.g. within special zones) to facilitate social learning and intensive interactions related to the basic but changing interests of a given community (Bilandzic \& Foth, 2013), including learners/students and teachers. According to the previously quoted P. Temple (2019), "[...] students seek out learning spaces with particular characteristics, depending on personal preferences, the application of which then influence further use of the spaces" (p. 229).

According to the DIDEL report "Learning Experiments in the Libraries"12 the competences of librarians should be complemented by the competences of educators. The publication (as part of the project "Daily Innovators and Daily Educators in the Libraries") also highlights the four spaces and goals of the library, e.g. the inspiration space. One of the goals is to support innovation. Moreover, today's libraries (especially pedagogical ones), which are cooperating with other institutions, are becoming educational and vocational information centres for students and teachers - advisers. They provide content related, among other things, to mobility and flexibility on the labour market (Rosak, 2015).

In university libraries - flexible spaces for learning and exchange of knowledge next to places for teamwork, there are and will be quiet spaces for learning, but with the possibility of quick, temporary modification of places according to the needs of users. It is also a trend to include academic (classrooms, computer labs) and non-academic units (e.g. art galleries, writing studios) in libraries, and to involve the academic community in space design (Cunningham \& Tabur, 2012). Experiences with participatory design can be used in education - in the innovative process, its creative phase.

It is worth adding that technology and knowledge transfer centres operating in or around universities, as well as makerspaces and digital fabrication laboratories, strive for the development of the local community (similarly to higher schools,

12 The project and the report are available at: https://biblioteki.org/. 
which care about relations with the socio-economic environment - according to the author of this text) and cooperation within the community of practice. The creators - often supported by modern information technologies - present their projects and share their knowledge and experience through geographic proximity or cognitive proximity (Capdevila, 2018).

In addition, the described spaces and pro-innovative activities (examples from different countries) - with their services - cover a wide range of users, including students and graduates, and support, among others, teaching (non-standard working methods and tools e.g. design thinking method) and research. They also expand the educational offer of universities (e.g. by pedagogical innovations) and provide wider access to practitioners, advisors and mentoring. Thanks to them, the group of potential partners: business people, co-workers, academics, education consultants and members of project teams - is growing. They inspire and create conditions for undertaking artistic, educational, social and (pro)professional actions.

\section{References}

Bąkowski A. (2012). Centra Transferu Technologii. In: A. Bąkowski, M. Mażewska (ed.). Ośrodki innowacji i przedsiębiorczości w Polsce. Raport 2012. Warsaw: Polish Agency for Enterprise Development (PARP), pp. 84-86.

Bilandzic, M., Foth, M. (2013). Libraries as co-working spaces: Understanding user moti-vations and perceived barriers to social learning. „Library Hi Tech”, 31 (2), 254-273, https://doi.org/10.1108/07378831311329040.

Capdevila I. (2018). Knowing communities and the innovative capacity of cities. „City, Culture and Society", 13, 8-12, https://doi.org/10.1016/j.ccs.2017.05.003.

Cunningham H., Tabur S. (2012). Learning space attributes: reflections on academic library design and its use. „Journal of Learning Spaces”, 1 (2). Retrieved from http://libjournal. uncg.edu/jls/article/view/392/287.

Drozdowski R., Zakrzewska A., Puchalska K., Morchat M., Mroczkowska D. (2010). Wspieranie postaw proinnowacyjnych przez wzmacnianie kreatywności jednostki. Seria „Innowacje”. Warsaw: Polish Agency for Enterprise Development (PARP), pp. 20, 68-69.

Duarte C., Mendes F. (2016). Coworking: Open and Informal Design Classroom. Design Doctoral Conference'16. IADE-U. Portugal. Retrieved May 20, 2021, from: https://coworkinglibrary.com/publication/coworking-open-and-informal-design-classroom/.

Cagnol R. (2013). Will Coworking Spaces Be The New Classrooms? Retrieved from: https://www.deskmag.com/en/coworking-spaces/will-coworking-spaces -be-the-new-classrooms-university-school-686.

Eurofound (2015). New forms of employment. Publications Office of the European Union. Luxembourg, pp. 120-121. Retrieved from: https://www.eurofound.europa.eu/sites/ default/files/ef_publication/field_ef_document/ef1461en.pdf.

European Commission, OECD (2005). Oslo Manual. Guidelines for Collecting and Interpreting Innovation Data. 3rd edition. Paris, pp. 57-58. 
Google for Startups (2020). Tak tworzyła się historia - 5 lat Google for Startups w Europie Srodkowo-Wschodniej [Five years of Google for Startups in Central and Eastern Europe], listopad, pp. 46-61. Retrieved from: https://www.campus.co/warsaw/weturn5/.

Grudzewski W.M., Hejduk I. (2004). Efektywność działalności innowacyjnej przedsiębiorstw. In: Okoń-Horodyńska E. (ed.). Rola polskiej nauki we wzroście innowacyjności gospodarki. Warsaw: Polish Economic Society (PTE).

Information about the AccessEngineering project, https://www.washington.edu/doit/ making-makerspace-guidelines-accessibility-and-universal-design.

Information about the Innovating Pedagogy Reports, http://www.open.ac.uk/blogs/ innovating/.

Jonhson C., Are Coworking Spaces the Classrooms of the Future? Retrieved May 20, 2021, https://coworkinginsights.com/coworking-spaces-the-classrooms-of-the-future/.

Koszowska A. (2019). Twórcze przestrzenie w bibliotekach publicznych - jak to działa w Polsce? „Biuletyn EBIB”, nr 6 (189).

Wizje, trendy, perspektywy - czy to jeszcze biblioteka? Retrieved from: http://ebibojs.pl/ index.php/ebib/article/view/568.

Kulpa-Puczyńska A. (2013). Higher school as an institution supporting innovative activities held by companies. Selected problems. „Problemy Profesjologii”, 1, 89-10o.

Madalińska-Michalak J. (2020). Edukacja zdalna i zachowania innowacyjne nauczycieli. „Forum Oświatowe”, 32 (2), 53-71, https://doi.org/10.34862/fo.2020.2.2.

Marody M. (2014). O społecznym zakorzenieniu kultury uniwersytetu. „Nauka”, nr 2, 27-32.

Matusiak K.B. (2010). Centra Transferu Technologii. In: Matusiak K.B. (ed.). Ośrodki innowacji i przedsiębiorczości w Polsce. Raport 2010. Warsaw: Polish Agency for Enterprise Development (PARP), p. 88.

Orzeszko E. (2020). Fablaby jako środowiska uczenia się osób dorosłych. Retrieved from: ttps://epale.ec.europa.eu/pl/blog/fablaby-jako-srodowiska-uczenia-sie-osob-doroslych.

Przepiórkowski M. (2018). Droga humanistyki praktycznej - między ideq humboldtowska a uniwersytetem przedsiębiorczym. „Edukacja”, 3 (146), 5-16. DOI 10.24131/3724.1803001.

Przyborowska B. (2013). Pedagogika innowacyjności. Między teoria a praktyką. Toruń: Wydawnictwo Uniwersytetu Mikołaja Kopernika.

Rogers E.M. (2003). Diffusion of innovations. New York: Free Press, after: K.B. Matusiak (2010). Budowa powiązań nauki z biznesem w gospodarce opartej na wiedzy. Rola i miejsce uniwersytetu w procesach innowacyjnych. Warsaw: Oficyna Wydawnicza SGH.

Rosak M. (2015). Informacja edukacyjno-zawodowa dla publicznych bibliotek pedagogicznych. Warsaw: Krajowy Ośrodek Wspierania Edukacji Zawodowej i Ustawicznej, pp. 22-24.

Siemieniuk Ł. (2017). Wybrane aspekty funkcjonowania Akademickich Inkubatorów przedsiębiorczości w Polsce. „Optimum. Studia Ekonomiczne”, 6 (90), 79-92. DOI: 10.15290/ ose.2017.06.90.07.

Sinclair B. (2007). Commons 2.0: Library Spaces Designed for Collaborative Learning. 
Stachura P., Kuligowska K. (2018). Coworking - geneza zjawiska i perspektywy rozwoju. „Annales Universitatis Mariae Curie-Skłodowska”, sectio H - Oeconomia, 52 (2), 153-16o, http://dx.doi.org/10.17951/h.2018.52.2.153-16o.

Sztompka P. (2016). Kapitał społeczny. Teoria przestrzeni międzyludzkiej. Cracow: Wydawnictwo Znak.

Temple P. (2019). University spaces: Creating cité and place. London Review of Education, 17 (2), 223-235. DOI https://doi.org/10.18546/LRE.17.2.o9.

Tidd J., Bessant J. (2011). Zarządzanie innowacjami. Integracja zmian technologicznych, rynkowych i organizacyjnych. Warsaw: Wolters Kluwer.

Trow M. (2010). The campus as a context for learning: Notes on education and architecture.

In: Trow M. Twentieth-Century Higher Education: Elite to mass to universal. Burrage, Baltimore M. (ed.). MD: Johns Hopkins University Press. After: Temple P. (2019).

University spaces: Creating cité and place. „London Review of Education”, 17 (2), 223-235. DOI https://doi.org/10.18546/LRE.17.2.09.

Polish Act of July 20, 2018 - Law on Higher Education and Science („Journal of Laws" 2021, 478 consolidated text, binding version from: April 3, 2021, to: June 30, 2021). Retrieved from: https://sip.lex.pl/akty-prawne/dzu-dziennik-ustaw/ prawo-o-szkolnictwie-wyzszym-i-nauce-1875040o/art-148.

Vincent-Lancrin S., Jacotin G., J. Urgel S., Kar and C. González-Sancho (2017). Measuring Innovation in Education. „A Journey to the Future”. Paris: OECD Publishing, pp. 34-35. Retrieved from: https://www.oecd.org/education/ceri/Measuring_Innovation_16x23_ ebook.pdf.

World Economic Forum (2020). The Future of Jobs Report 2020. October, pp. 35-36. Retrieved from: https://www.weforum.org/reports/the-future-of-jobs-report-2020.

\section{UNIWERSYTECKIE PRZESTRZENIE WSPÓŁPRACY WZMACNIAJACE POSTAWY PROINNOWACYJNE SPOŁECZNOŚCI AKADEMICKIEJ}

Streszczenie: Artykuł i podjęty w nim temat wpisują się w dyskusję dotyczącą proinnowacyjnego charakteru szkoły wyższej - podając przykłady działań (głównie edukacyjnych) na rzecz innowacji w kampusie uczelni i poza nim oraz odnosząc się do tendencji w analizowanych obszarach. W tekście ograniczono się do społecznego wymiaru innowacji, zmieniających m.in. sposób postrzegania świata i relacji międzyludzkich, dotyczących także organizacji miejsc i metod (współ)pracy. Celem artykułu jest również zwrócenie uwagi na udział studentów, nauczycieli akademickich w różnych aktywnościach (też proinnowacyjnych) nietradycyjnej infrastruktury społecznej. Analizując problemy, oparto się na studiach literatury, m.in. raportów z badań nad innowacyjnością, jak i na doświadczeniach 
zawodowych autorki związanych $\mathrm{z}$ nowymi ${ }^{13}$ przestrzeniami edukacji, próbując także odpowiedzieć na pytanie: czy współdziałanie w ramach opisanych przestrzeni może wzmocnić postawy proinnowacyjne, także przyszłych pedagogów?

Słowa kluczowe: uniwersytet, przestrzenie współpracy, postawy proinnowacyjne, społeczność akademicka, edukacja na rzecz innowacji, kooperacja uczelni ze środowiskiem lokalnym.

13 Chodzi tutaj, podobnie jak w przypadku innowacji (szersze podejście definicyjne), o element nowości. Na przykład, produkt, proces czy metoda organizacyjna zostały już wdrożone w innych firmach, jednak są one nowe dla danego przedsiębiorstwa. Innowacje są też efektem współpracy firm lub ich kooperacji z publicznymi instytucjami badawczymi, mogą być również tworzone poza przedsiębiorstwem (European Commission, OECD, 2005). Innowacja to „idea, praktyka lub obiekt, który jest postrzegany jako nowy przez osobę lub jednostkę przyjmującą" (Rogers, 2003, p.12, after: Matusiak, 2010, p. 21). 
